\title{
CORPORATE SOCIAL RESPONSIBILITY SEBAGAI VARIABEL INTERVENING HUBUNGAN FAMILY OWNERSHIP DAN KINERJA PERUSAHAAN
}

\author{
Rezky Pramurindra ${ }^{1 *}$, Wita Ramadhanti ${ }^{1}$, Eliada Herwiyanti ${ }^{1}$, Pretisila Kartika Putri ${ }^{1}$ \\ 1Jurusan Akuntansi, Fakultas Ekonomi dan Bisnis, Universitas Jenderal Soedirman, Indonesia \\ *Email corresponding author: rezky.pramurindra@gmail.com \\ Diterima 07/08/2020 Direvisi 19/01/2021 Diterbitkan 31/01/2021
}

\begin{abstract}
Abstrak
Kebijakan dan operasional perusahaan memegang peranan penting bagi kelangsungan suatu perusahaan. Sudah bukan rahasia lagi bahwa manajer suatu perusahaan masih mempunyai hubungan keluarga dengan pemilik perusahaan. Tentu keputusan ini bukan semata masalah kepercayaan antara pemilik terhadap keluarganya, tetapi juga karena perspektif keluarga yang memandang perusahaan sebagai aset keluarga yang harus diteruskan kepada generasi berikutnya. Oleh karena itu, unsur keluarga dapat berpengaruh secara langsung maupun tidak langsung terhadap kebijakan dan operasional perusahaan. Penelitian ini bertujuan untuk menguji hubungan kausalitas antara family ownership dan kinerja perusahaan dengan corporate social responsibility sebagai variabel intervening. Populasi penelitian merupakan seluruh perusahaan industri sektor infrastruktur, utilitas dan transportasi serta industri properti, real estate dan konstruksi bangunan yang terdaftar di Bursa Efek Indonesia periode tahun 2018. Penggunaan teknik purposive sampling menghasilkan 65 family business yang digunakan sebagai sampel penelitian. Pengujian hipotesis menggunakan SmartPLS 3.0 menghasilkan: (1) Family ownership berpengaruh positif dan signifikan terhadap kinerja perusahaan; (2) Family Ownership berpengaruh positif dan signifikan terhadap corporate social responsibility; (3) Corporate social responsibility memediasi pengaruh family ownership terhadap kinerja perusahaan keluarga. Hasil penelitian memberikan alternatif struktur kepemilikan bagi perusahaan untuk menghadapi tantangan revolusi industri 4.0 dan rekomendasi bagi family business dalam menganalisis komponen-komponen yang dapat mempengaruhi kinerja perusahaan.
\end{abstract}

Kata Kunci: Family Ownership, Family Business, Corporate Social Responsibility, Kinerja Perusahaan

\begin{abstract}
Company policies and operations play an important role for the survival of a company. It is no secret that the manager of a company is still related to the owner of the company. Of course, this decision is not only a matter of trust between the owner of his family, but also because of the family perspective that views the company as a family asset that must be passed on to the next generation. Therefore, family elements can influence directly or indirectly on company policies and operations. This study aims to examine the causal relationship between family ownership and company performance with corporate social responsibility as an intervening variable. The research population is all industrial companies in the infrastructure, utilities and transportation sectors as well as the property, real estate and building construction industries listed on the Indonesia Stock Exchange for the period 2018. The use of purposive sampling technique resulted in 65 family businesses used as research samples. Hypothesis testing using SmartPLS 3.0 results in: (1) Family ownership has a positive and significant effect on company performance; (2) Family Ownership has a positive and significant effect on corporate social responsibility; (3) Corporate social responsibility mediates the influence of family ownership on the performance of family companies. The results of the study provide an alternative ownership structure for companies to face the challenges of the industrial revolution 4.0 and recommendations for family businesses in analyzing the components that can affect company performance.
\end{abstract}

Key Words: Family Ownership, Family Business, Corporate Social Responsibility, Company Performance 


\section{PENDAHULUAN}

Era otomatisasi dan interkonektivitas industri 4.0 membuat dunia usaha tidak lagi mengenal batas-batas negara. Perusahaan tidak hanya menghadapi persaingan nasional tetapi juga multinasional. Oleh karena itu, perusahaan dituntut untuk mampu menyelaraskan semua kepentingan prinsipal dan agen untuk berorientasi pada pencapaian tujuan perusahaan (Yusuf, 2019). Disisi lain, hasil survei Association of Certified Fraud Examiners (ACFE) menunjukkan bahwa 40,3\% kasus fraud di Indonesia dilakukan oleh middle management atau level manajer (Association of Certified Fraud Examiners (ACFE), 2016). Informasi dan pemahaman lebih yang dimiliki terhadap kondisi perusahaan, memungkinkan manager untuk mengeksploitasi atau mengambil alih sumber daya perusahaan (Miller, Danny., Bretton-Miller, 2006). Agency theory (Jensen, Michael. C., Meckling, 1976) telah mengungkapkan fenomena ini, bahwa asimetri informasi yang dimiliki agen dan konflik kepentingan dengan prinsipal, menyebabkan terjadinya moral hazard yang merugikan perusahaan. Manajer akan berkerja untuk kepentingan mereka sendiri dengan mengabaikan kepentingan perusahaan yang semestinya (Charbel, Salloum., Elie, Bouri., Georges, Samara, 2013).

Penelitian yang dilakukan oleh (Perdana, Ida, BP., Kusumastuti, 2011), (Pindado, Julio., Requejo, Ignacio., Toree, 2008), (Yoshikawa, Toru., Rasheed, 2010), serta (Charbel, Salloum., Elie, Bouri., Georges, Samara, 2013) menemukan bahwa perusahaan yang dijalankan oleh keluarga dapat meminimalisir agency problem antara prinsipal dan agen. Keterlibatan keluarga terhadap manajemen perusahaan akan membuat manajer tidak bisa mengambil alih kekayaan perusahaan, baik melalui manipulasi informasi keuntungan maupun pengalokasian sumber daya (Atmaja Lukas, 2008). Perspektif keluarga menganggap bahwa perusahaan merupakan aset keluarga yang harus diteruskan kepada generasi berikutnya, sehingga mereka akan meningkatkan fungsi pengendalian dan pengawasan untuk menjamin tercapainya tujuan perusahaan (Yovita, Finda., 2017). Kehadiran pendiri atau anggota keluarga dalam perusahaan akan menyelaraskan kepentingan prinsipal dan agen, sehingga agency cost dapat diminimalisir (Charbel, Salloum., Elie, Bouri., Georges, Samara, 2013).

Family Business memiliki peran penting dalam perekonomian dunia (Charbel, Salloum., Elie, Bouri., Georges, Samara, 2013). Data menunjukkan bahwa terdapat sekitar 24 juta bisnis keluarga di Amerika Serikat yang memberikan sumbangan terhadap Gross Domestic Product (GDP) sebesar $64 \%$ atau US\$ 5,9 triliun dan menyerap 82 juta tenaga kerja (Astrachan, Joseph, H., Shanker, M, 2003). Data di wilayah Timur Tengah mencatat bahwa kegiatan komersil negara Arab Saudi, Kuwait, Qatar, Uni Emirat Arab dan Oman yang tergabung dalam Gulf Cooperation Council, 98\% dimiliki maupun dikendalikan oleh keluarga (Charbel, Salloum., Elie, Bouri., Georges, Samara, 2013). Selanjutnya, family business merepresentasikan 55-90\% bisnis di setiap negara Eropa (International, 2018). Sementara, menurut data Indonesian Institute for Corporate and Directorship (IICD), family business menguasai hampir 95\% bisnis baik berskala mikro, kecil, menengah maupun besar di Indonesia (Soerjonodibroto, 2010). Lebih lanjut data Biro Pusat Statistik (BPS) menunjukkan bahwa 82,44\% Produk Domestik Bruto (PDB) merupakan kontribusi dari family business di Indonesia (Marpa, 2012).

Perekonomian sebuah negara tidak terlepas dari kebijakan yang dikeluarkan pemerintah (Lam, Newman, 2000). Program prioritas pemerintah Indonesia yang bertajuk Nawacita telah memberikan dampak signifikan terhadap sektor infrastruktur dan properti (Syamsi, Syam, 2015). Dalam UU No. 12 Tahun 2018 tentang APBN 2019, pemerintah mengalokasikan anggaran infrastruktur mencapai Rp. 415 triliun atau 25,39\% dari total belanja APBN. Sejalan dengan kebijakan ini, data statistik yang tercatat di Indonesian Stock Exchange atau Bursa Efek Indonesia (BEI) menunjukkan pergerakan harga saham sektoral infrastruktur dan properti mengalami tren positif tertinggi sebesar 17,90\% dan 17,67\% selama periode September 2018-September 2019 (IDX Statistic, 2019). Fenomena ini memunculkan pertanyaan, apakah family business ada dan berkontribusi terhadap pertumbuhan ekonomi ini? 
Performance. Volume 28 Nomor 1 Tahun 2021, 63-81

Tagiuri dan Davis (1978) mengembangkan konsep Three Circle Model of The Family Business System sebagai kerangka dasar untuk memahami family business. Family circle (keluarga), business circle (perusahaan) dan ownership circle (kepemilikan) merupakan satu kesatuan model yang saling mempengaruhi dan tidak dipisahkan satu sama lain (Davis, 2018). Keluarga mempengaruhi kebijakan dan operasional perusahaan melalui posisi manajemen, hak kepemilikan, dan peran keluarga terhadap perusahaan (Villalonga dan Amit, 2006). Studi literatur yang dilakukan Astrachan dan Shanker (2003), (Muttakin, 2012), Perdana dan Kusumastuti (2011), Pindado et al. (2008), Brand et.al, (2018), serta Yoshikawa dan Rasheed (2010) menunjukkan bahwa family ownership berpengaruh positif terhadap kinerja perusahaan. Penelitian Charbel et al. (2013), Miller dan Bretton-Miler (2006) mengungkapkan bahwa family business memiliki kinerja yang lebih baik dibandingkan dengan perusahaan non-keluarga. Namun demikian, beberapa literatur lain menunjukkan hasil yang berlawanan, family ownership memberikan dampak negatif terhadap kinerja perusahaan (Yovita dan Juniarti, 2017, (Tanzil, Stephanie, N., 2017), (Wiranata, Yulius, A., Nugrahanti, 2013), Maseda et al., 2018, (Foroughi, Meysam., Fooladi, 2011) Villalonga dan Amit (2006) menemukan bahwa family ownership hanya akan menambah nilai perusahaan apabila pendiri masih aktif sebagai CEO atau menjabat chairman dengan CEO bukan anggota keluarga. Sedangkan dalam kasus reksa dana, tidak ada dampak kepemilikan keluarga dalam keputusan investasi asing perusahaan yang dapat dilihat (Manogna \& Kumar, 2020).

Adanya ketidakkonsistenan pada hasil penelitian, menimbulkan dugaan bahwa ada variabel lain yang mempengaruhi hubungan family ownership dengan kinerja perusahaan. Pricewaterhouse Cooper (PwC) dalam survei bertajuk "Family Firm: A Resilient Model for the 21st Century" menemukan kualitas unik family business, yaitu: (1) Berorientasi pada kelangsungan usaha jangka panjang perusahaan; (2) Keputusan bisnis bersifat fleksibel dan menjunjung tinggi nilai-nilai keluarga; (3) Ada entrepreneurial mindset, (4) Berkomitmen terhadap peningkatan kesejahteraan masyarakat melalui pembukaan lapangan kerja, serta (5) Memiliki pendekatan bisnis yang lebih personal. Data survei PwC menunjukkan bahwa 77\% responden menganggap bahwa family business memiliki tanggung jawab sosial dan kepedulian yang lebih besar terhadap karyawan dan kesejahteraan masyarakat (PwC (Pricewaterhouse Cooper), 2012). Pelaksanaan tanggung jawab sosial inilah yang kemudian dikaitkan dengan Corporate Social Responsibility (CSR).

Family business memiliki perspektif bahwa reputasi perusahaan tidak hanya mencerminkan kinerja perusahaan, tetapi juga nama baik keluarga (Ghoul, S.E., Guedhami O., Kwok C.C.Y., 2016). Keluarga sebagai pemilik perusahaan akan memberikan perhatian lebih besar terhadap aktivitasaktivitas yang berpengaruh positif terhadap reputasi perusahaan (Deephouse, David L., Carter, 2013). Beberapa penelitian telah dilakukan untuk menguji pengaruh family ownership terhadap corporate social responsibility (CSR). (Liu, Mingzhi., Shi Y., Wilson C., 2017) yang mengungkapkan bahwa perusahaan dengan family involvement lebih bertanggungjawab secara sosial dibandingkan perusahaan tanpa family involvement. Palma et al. (2018) menemukan bahwa family business memiliki pengungkapan sustainability reporting yang lebih baik dibandingkan perusahaan nonkeluarga. Selanjutnya, Ghoul et al. (2016) dalam penelitiannya menunjukkan bahwa family control memiliki pengaruh signifikan terhadap corporate social responsibility (CSR). Tinjauan sistematis dalam penelitian (Lv et al., 2020) juga menemukan bahwa terdapat hubungan positif antara CSR dan kinerja keuangan, kinerja sosial dan inovasi bisnis keluarga, yang mendukung Teori Sosioemosional dan Teori Pemangku Kepentingan.

Berdasarkan fenomena ekonomi dunia yang dikendalikan oleh family business dan urgensi mengelola agency problem untuk menghadapi persaingan global, maka sangat penting untuk mempelajari family business dan komponen yang dapat mempengaruhi kinerja mereka. Family ownership sebagai representasi unsur keluarga dalam perusahaan, telah dibuktikan secara teoritis memiliki pengaruh positif terhadap perusahaan. Penelitian Charbel et al. (2013), Miller dan Bretton-Miler (2006) telah menunjukkan bahwa family business memiliki kinerja yang lebih baik dibandingkan dengan perusahaan non-keluarga. Namun demikian, studi literatur lain 
Performance. Volume 28 Nomor 1 Tahun 2021, 63-81

menunjukkan hasil yang berlawanan, family ownership akan memberikan dampak negatif terhadap kinerja perusahaan. Oleh karena itu, penelitian ini menggunakan variabel corporate social responsibility (CSR) sebagai variabel yang memediasi pengaruh tidak langsung family ownership terhadap kinerja perusahan atau yang disampaikan (Baron, M, Reuben., Kenny, A, 1986) sebagai variabel intervening. Teori stakeholder memberikan pandangan bahwa pemenuhan kepentingan para stakeholder merupakan kunci sukses peningkatan nilai perusahaan (Tjipto, Elsa, P., 2016). Perspektif reputasi dan orientasi jangka panjang yang dimiliki family business, akan mendorong perusahaan berinvestasi lebih besar pada kegiatan CSR untuk mencapai kinerja perusahaan yang lebih baik.

\section{TINJAUAN PUSTAKA DAN PERUMUSAN HIPOTESIS}

\section{Teori Agensi (Agency Theory)}

Ketidakmampuan teori perusahaan untuk menjelaskan perilaku manajerial (manajerial behaviour) dalam perusahaan, memotivasi Jensen dan Meckling (1976) untuk mengintegrasikan unsur behavior (perilaku) ke dalam teori struktur kepemilikan perusahaan. Jensen dan Meckling (1976) dalam artikel "Theory of The Firm: Manajerial Behaviour, Agency Cost and Ownership Structure" menjelaskan hubungan agensi sebagai sebuah kontrak antara satu orang atau lebih (prinsipal) dan orang lain yang ditunjuk sebagai agen, untuk memberikan jasa atas nama prinsipal dengan pendelegasian beberapa wewenang untuk pengambilan keputusan. Prinsipal atau pemegang saham menginginkan arus kas perusahaan dialokasikan untuk pembagian deviden. Sementara disisi lain, manajer akan lebih memprioritaskan penggunaan arus kas untuk membiayai proyek atau instrumen keuangan yang menghasilkan penjualan yang besar untuk mendapatkan reward yang tinggi (Mutakkin, 2012). Adanya dua kepentingan yang berbeda ini akan menimbulkan konflik kepentingan dalam perusahaan.

Manajer lebih memahami kondisi dan prospek perusahaan serta informasi internal yang tidak dimiliki prinsipal (Hidayanti, 2013). Manajer cenderung tidak menyampaikan kondisi perusahaan yang sebenarnya kepada pemilik (Luayyi, 2012). Adanya asimetri informasi dan konflik kepentingan yang menyebabkan terjadinya agency problem dan moral hazard manajer untuk mengeksploitasi atau mengambil alih sumber daya perusahaan (Miller dan Breton-Miller, 2006). Masalah moral hazard terjadi ketika manajer bekerja untuk kepentingan mereka sendiri dengan mengabaikan kepentingan perusahaan yang semestinya (Charbel et al., 2013). Manajer akan membuat banyak keputusan berisiko tinggi yang akan membebani perusahaan dan pemegang saham (Purnamasari, 2018). Manajer akan memilih mengambil investasi beresiko tinggi yang akan memberikan return yang besar, tanpa berfikir resiko jangka panjang yang akan dihadapi perusahaan (Charbel et al., 2013).

Ketika perusahaan dimiliki atau dikendalikan oleh keluarga, agency problem dapat diminimalisir (Miller dan Breton-Miller, 2006). Kehadiran pendiri atau anggota keluarga dalam manajemen dapat menyelaraskan kebijakan insentif prinsipal terhadap agen (Jensen dan Meckling, 1976). Preferensi ekonomi dan non-ekonomi family business terhadap kelanjutan perusahaan akan meningkatkan sense of belonging anggota keluarga terhadap perusahaan (Maseda, Amaia., Itturalde T., Aparicio G., Boulkeroua L., 2018). Mereka akan meningkatkan fungsi pengendalian dan pengawasan terhadap kebijakan dan operasional perusahaan untuk menjamin tercapainya tujuan perusahaan (Yovita dan Juniarti, 2017). Hal ini membuat manajer tidak bisa mengambil alih kekayaan perusahaan, baik melalui manipulasi informasi keuntungan maupun pengalokasian sumber daya (Atmaja, 2008). Dengan demikian, keterlibatan keluarga dalam perusahaan dapat meminimalkan terjadinya moral hazard dan agency problem antara prinsipal dan agen. 
Performance. Volume 28 Nomor 1 Tahun 2021, 63-81

Teori Stakeholder (Stakeholder Theory)

Teori Stakeholder menggambarkan perusahaan sebagai serangkaian koneksi semua stakeholder (pemangku kepentingan) yang berusaha dikelola perusahaan (Moir, 2001). R. Edward Freeman (1984) dalam buku berjudul "Strategic Management: A Stakeholder Approach" mendefinisikan stakeholder sebagai individu atau kelompok yang dapat dipengaruhi atau mempengaruhi pencapaian tujuan perusahaan (Roberts, W, 1992). (Clarkson, M, B, 1995) membagi stakeholder ke dalam 2 (dua) kategori, primary dan secondary stakeholder. Primary stakeholder merupakan kelompok yang memiliki partisipasi berkelanjutan dalam perusahaan, termasuk investor atau pemegang saham, karyawan, pelanggan, supplier serta kelompok stakeholder publik, seperti pemerintah dan komunitas yang menyediakan infrastruktur dan market. Secondary stakeholder didefinisikan sebagai pihak yang dapat dipengaruhi atau mempengaruhi perusahaan tetapi mereka tidak terlibat dalam kebijakan dan operasional perusahaan, seperti society (masyarakat).

Teori stakeholder memberikan suatu pandangan bahwa kelangsungan hidup jangka panjang perusahaan berkaitan dengan pemenuhan kepentingan ekonomi dan non-ekonomi para stakeholder melalui kegiatan CSR (Tjipto dan Juniarti, 2016). Pemenuhan kepentingan stakeholder menjadi kunci sukses peningkatan nilai perusahaan, karena akan menghindarkan perusahaan dari kemungkinan biaya yang diakibatkan stakeholder. Turnover karyawan yang rendah akan mengurangi biaya rekrutmen dan pelatihan karyawan, supplier yang loyal akan mengurangi biaya sertifikasi kualitas, masyarakat yang mendukung aktivitas dan operasional perusahaan akan mengurangi biaya hukum atas kemungkinan pengaduan dan tuntutan penghentian perusahaan serta pemegang saham yang stabil akan mengurangi volalitas pasar (McVea, John F., Freeman, 2005). Perusahaan harus mampu mengidentifikasi kebutuhan stakeholder, merancang kebijakan, dan pratik organisasi yang tepat melalui kegiatan CSR untuk menjamin kelangsungan usaha (Mishra, Supriti., Suar, 2010).

\section{Pengembangan Hipotesis}

Pengembangan hipotesis penelitian menggunakan konsep variabel mediasi yang dikembangkan Baron dan Kenny (1986) dalam artikel "The Moderator-Mediator Variable Distinction in Social Pschological Research: Conceptual, Strategic and Statistical Considerations".

\section{Pengaruh Family Ownership terhadap Kinerja Perusahaan}

Konsep family business tidak bisa dipisahkan dari Three Circle Model of The Family Business System yang disampaikan Renato Tagiuri dan John Davis (1978). Family circle (keluarga), business circle (perusahaan) dan ownership circle (kepemilikan) merupakan satu kesatuan model yang saling mempengaruhi dan tidak dipisahkan satu sama lain (Davis, 2018). Marpa (2012) dalam buku "Perusahaan Keluarga: Sukses atau Mati" menyebutkan bahwa ownership circle telah menjadi variabel independen yang membentuk setiap dimensi hubungan keluarga dan perusahaan. Jensen dan Meckling (1976) mengungkapkan bahwa kehadiran keluarga dalam perusahaan akan menyelaraskan kepentingan prinsipal dan agen. Mitigasi agency problem dan aliansi kepemilikan keluarga dengan manajemen akan memungkinkan perusahaan untuk mencapai kinerja keuangan yang lebih baik (Villalonga, B., Amit, 2006). Penelitian (Camisón-Zornoza et al., 2020) juga menemukan bahwa kepemilikan keluarga berhubungan positif dengan kinerja perusahaan.

Perspektif keluarga menganggap bahwa perusahaan adalah aset keluarga yang harus diteruskan kepada anggota keluarga (Yovita dan Juniarti, 2017). Mereka memiliki komitmen dan sense of belonging yang tinggi untuk bagaimana caranya mempertahankan dan mengembangkan usaha keluarga (Marpa, 2012). Perspektif ini yang mendorong family business untuk berfokus pada kelangsungan hidup jangka panjang perusahaan (Brandt, 2018). Manajemen keluarga dapat membuat keputusan investasi yang lebih baik, karena mereka memiliki orientasi bisnis jangka panjang, sehingga dapat menghindarkan perusahaan dari keuntungan jangka pendek atau manajerial myopia dan mengarah pada kinerja perusahaan yang lebih baik (Charbel et al., 2013). 


\section{PERFORMANCE}

Jurnal Personalia, Financial, Operasional,

Marketing dau Sistem Informasi

Performance. Volume 28 Nomor 1 Tahun 2021, 63-81

Sebagaimana telah dibuktikan secara empiris dalam penelitian Astrachan dan Shanker (2003), Muttakin (2012), Perdana dan Kusumastuti (2011), Brand et.al, (2018), Pindado et al. (2008), Yoshikawa dan Rasheed (2010) yang menunjukkan bahwa family ownership berpengaruh positif terhadap kinerja perusahaan. Selanjutnya, Penelitian Charbel et al. (2013), Miller dan BrettonMiler (2006) menemukan bahwa family business memiliki kinerja yang lebih baik dibandingkan dengan perusahaan non-keluarga. Dengan demikian, perumusuan hipotesis yang dapat disusun: $\mathrm{H}_{1}$ : Family ownership berpengaruh positif terhadap kinerja perusahaan.

\section{Pengaruh Family Ownership Terhadap Corporate Social Responsibility}

Reputasi perusahaan tidak hanya mencerminkan kinerja perusahaan, tetapi juga nama baik keluarga (Dyer, W., Whetten, 2006). Reputasi mencerminkan evaluasi stakeholder (pemangku kepentingan) tentang seberapa baik perusahaan memenuhi harapan relatif mereka (Deephouse dan Carter, 2005). Perusahaan berinvestasi dalam kegiatan CSR untuk meningkatkan reputasi mereka dihadapan para stakeholder (Ghoul et al., 2016). Pemilik dan anggota keluarga memandang bahwa reputasi perusahaan yang buruk akan menghancurkan nama baik keluarga dan kinerja perusahaan itu sendiri (Dyer dan Whetten, 2006). Argumen ini menunjukkan bahwa family business memiliki dorongan yang besar untuk berinvestasi dalam kegiatan CSR untuk meningkatkan reputasi perusahaan dan nama baik keluarga.

Family business memiliki orientasi dan strategi bisnis jangka panjang (Palma, Marta., Lourenco I.C., Branco, 2018). Kepemilikan keluarga merupakan aset yang harus diteruskan kepada generasi selanjutnya (Yovita dan Juniarti, 2017). Perspektif ini mendorong family business untuk melakukan kegiatan bisnis yang tidak bertentangan dengan investor atau stakeholder (Davis, J.H., Allen, M.R., Hayes, 2010). Orientasi jangka panjang family business memungkinkan perusahaan untuk memaksimalkan kekayaan jangka panjang perusahaan dan berinvestasi jangka panjang dengan para stakeholder melalui kegiatan CSR (Miller dan Breton-Miller, 2005). Sejalan dengan argumen ini, Dyer dan Whetten (2006) menemukan bahwa family business di Amerika Serikat lebih bertangggung jawab secara sosial dibandingkan perusahaan non-keluarga. Selanjutnya, penelitian (Berrone, P., Cruz, C., Gómez-Mejía, L., Larraza-Kintana, 2010) menunjukkan bahwa perusahaan yang dikendalikan keluarga memiliki kinerja lingkungan yang lebih baik daripada perusahaan non-keluarga. Penelitian lain yang dilakukan Liu et al. (2017) mengungkapkan bahwa perusahaan dengan family involvement lebih bertanggungjawab secara sosial dibandingkan perusahaan tanpa family involvement.

Kerangka berfikir diatas telah menunjukkan bahwa reputasi dan perspektif jangka panjang family business mendorong perusahaan untuk berinvestasi lebih besar dalam kegiatan CSR, sehingga hipotesis kedua yang dapat disusun:

$\mathrm{H}_{2}$ : Family ownership berpengaruh positif terhadap corporate social responsibility

\section{Pengaruh Corporate Social Responsibility dalam Memediasi Hubungan Family Ownership terhadap Kinerja Perusahaan}

Stakeholder theory memberikan suatu pandangan bahwa pemenuhan kepentingan stakeholder merupakan kunci sukses peningkatan nilai perusahaan, karena akan menghindarkan perusahaan dari kemungkinan biaya yang diakibatkan stakeholder (Tjipto dan Juniarti, 2016). Turnover karyawan yang rendah akan mengurangi biaya rekrutmen dan pelatihan karyawan, supplier yang loyal akan mengurangi biaya sertifikasi kualitas, masyarakat yang mendukung aktivitas dan operasional perusahaan akan mengurangi biaya hukum atas kemungkinan pengaduan dan tuntutan penghentian perusahaan serta pemegang saham yang stabil akan mengurangi volalitas pasar (McVea dan Freeman, 2005). Hubungan terhadap stakeholder yang baik memiliki potensi untuk meningkatkan reputasi dan kinerja perusahaan, dibandingkan dengan strained relations yang akan berdampak negatif terhadap kinerja perusahaan (Mishra dan Suar, 2010). Seperti yang diungkapkan dalam penelitian Adeneye dan Ahmed (2015) terhadap 500 perusahaan di Inggris, menemukan bahwa corporate social responsibility berdampak positif dan 
Performance. Volume 28 Nomor 1 Tahun 2021, 63-81

signifikan terhadap kinerja perusahaan. Yang et al., (2019) menunjukkan bahwa aspek lingkungan, pelanggan, supplier, dan karyawan dalam dimensi CSR memiliki pengaruh positif signifikan terhadap indikator keuangan perusahaan.

CSR tidak lagi dipandang sebagai sebuah filantropi, tetapi menjadi strategi perusahaan untuk mempromosikan tujuan ekonomi perusahaan (Mishra dan Suar, 2010). Stakeholder cenderung melakukan transkasi dengan perusahaan yang memiliki catatan CSR yang baik, karena menunjukkan komitmen mereka kepada lingkungan dan masyarakat. CSR tidak hanya memberikan manfaat pada peningkatan loyalitas investor, tetapi juga loyalitas pelanggan, penerimaan masyarakat, dan peningkatan aset tak berwujud yang akan berdampak positif terhadap reputasi dan kinerja keuangan jangka panjang perusahaan (Palmer, 2012). Berkaitan dengan family ownership, perspektif reputasi dan orientasi jangka panjang mendorong family business berinvestasi lebih besar dalam kegiatan CSR untuk mencapai kinerja perusahaan yang lebih baik, sehingga perusahaan dapat berlanjut dari satu generasi ke generasi berikutnya. Sependapat dengan argumen ini, Deephouse dan Jaskiewicz (2013) mengungkapkan bahwa peningkatan aktivitas CSR pada perusahaan dapat memenuhi harapan relatif para pemangku kepentingan (stakeholder), yang akan direspon dengan peningkatan nilai perusahaan. Dengan demikian, CSR merupakan variabel intervening yang memediasi hubungan family ownership dan kinerja perusahaan.

$\mathrm{H}_{3}$ : Corporate social responsibility memediasi pengaruh family ownership terhadap kinerja perusahaan.

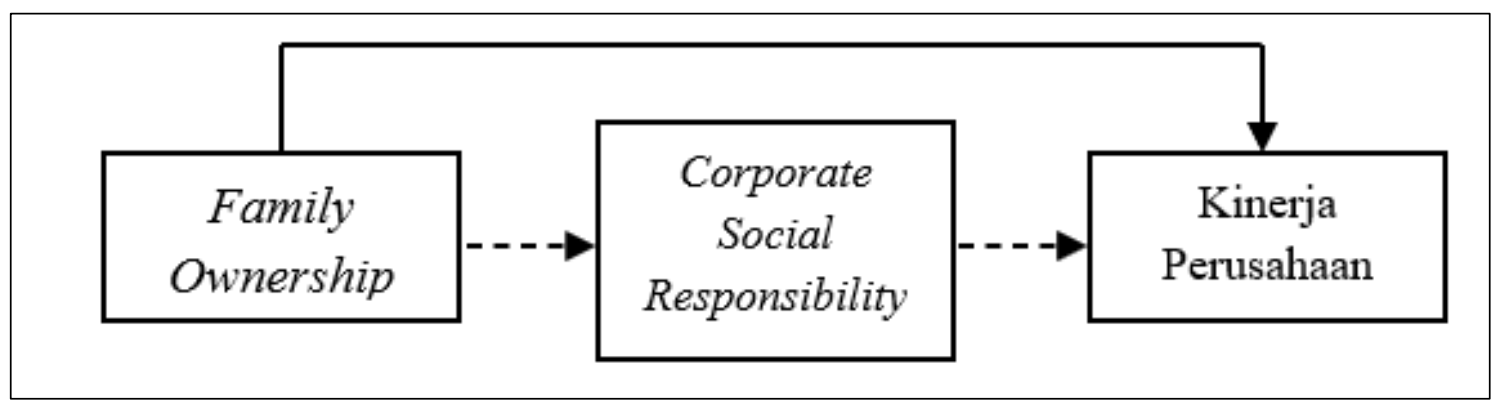

Gambar 1. Model Penelitian

\section{METODE PENELITIAN}

\section{Jenis Penelitian}

Penelitian ini merupakan penelitian kuantitatif yang bertujuan untuk menguji hubungan kausalitas antara family ownership dan kinerja perusahaan dengan corporate social responsibility sebagai variabel intervening. Metode dokumentasi digunakan dengan pendekatan content analysis (analisis konten) untuk memperoleh data dalam annual report (laporan tahunan) perusahaan.

\section{Populasi dan Teknik Sampling}

Populasi penelitian meliputi seluruh perusahaan industri sektor infrastruktur, utilitas dan transportasi serta industri properti, real estate dan konstruksi bangunan yang terdaftar di Bursa Efek Indonesia periode tahun 2018. Sampel penelitian diperoleh dengan menggunakan teknik purposive sampling. Pengembangan kriteria purposive sampling merujuk pada kriteria yang digunakan dalam penelitian (Perdana, Ida, BP., Kusumastuti, 2011) sebagai berikut: Sampel adalah perusahaan yang listing di Bursa Efek Indonesia periode 2018; Perusahaan beroperasi dalam bisnis infrastruktur, utilitas, transportasi dan atau industri properti, real estate serta konstruksi bangunan; Perusahaan memiliki persentase family ownership (kepemilikan keluarga) sebesar $\geq 20 \%$; Perusahaan mempublikasikan annual report dalam periode yang diteliti. 
Performance. Volume 28 Nomor 1 Tahun 2021, 63-81

\section{Jenis dan Sumber Data}

Data sekunder yang digunakan dalam penelitian bersumber dari publikasi annual report perusahaan pada website www.idx.co.id. Sustainability report tidak digunakan sebagai sumber data sekunder dalam pengungkapan corporate social responsibility. (Shoimah, Irma L., Aryani, 2019) menemukan bahwa hanya ada sekitar $8 \%$ perusahaan di Indonesia, yang menerbitkan sustainability report sebagai laporan CSR terpisah dari laporan tahunan.

\section{Definisi Konseptual dan Operasional Variabel Family Ownership}

Penelitian ini menggunakan pendekatan yang dikembangkan Villalonga dan Amit (2006) untuk menganalisis bagaimana family ownership (kepemilikan keluarga) mempengaruhi corporate social responsibility dan kinerja perusahaan. Family ownership merupakan kepemilikan satu atau lebih anggota keluarga terhadap saham suatu perusahaan, sehingga keluarga memiliki kendali yang signifikan atas perusahaan melalui hak suara. Sebuah perusahaan dianggap memiliki family ownership, apabila pendiri atau anggota keluarga menguasai kepemilikan perusahaan sebesar $\geq 20 \%$. Sejalan dengan argumen ini, standar akuntansi keuangan di Indonesia dalam PSAK 15 telah mengatur bahwa sebuah kepemilikan dianggap memiliki pengaruh signifikan secara kuantitatif apabila menguasai hak suara $\geq 20 \%$.

Variabel family ownership dinyatakan dalam bentuk persentase kepemilikan terhadap saham suatu perusahaan. Pengukuran family ownership menggunakan rumus yang digunakan dalam penelitian Ghoul et al. (2016) dan Mutakkin (2012):

$$
\text { Family Ownership }=\frac{\text { Jumlah saham dimiliki keluarga }}{\text { Total saham beredar }} \times 100 \%
$$

\section{Corporate Social Responsibility}

Mishra dan Suar (2010) mendefinisikan corporate social responsibility (CSR) sebagai kebijakan, proses, dan praktik perusahaan dalam mengidentifikasi kebutuhan dan kepentingan para stakeholder untuk mencapai keberlanjutan bisnis perusahaan. Standar Global Reporting Initiative (GRI)-G4 digunakan untuk mengukur variabel CSR. Indikator GRI menguraikan berbagai praktik bisnis perusahaan yang bertanggung jawab terhadap para stakeholder dalam hal dampak lingkungan, sosial dan ekonomi (Mishra dan Suar, 2010). Pendekatan content analysis digunakan untuk menghitung indeks CSRDI (Corporate Social Responsibility Disclosure) dengan memberikan skor 1 pada item yang diungkapkan dan skor 0 pada item yang tidak diungkapkan perusahaan berdasarkan 91 indikator GRI-G4. Skor dari setiap item dijumlahkan untuk memperoleh total skor item yang diungkapkan suatu perusahaan. Pengukuran CSRDI merujuk pada penelitian Haniffa dan Cooke (2005):

$$
\operatorname{CSRDI}_{J}=\frac{\sum X_{i j}}{n_{j}}
$$

Keterangan:

$\mathrm{CSRDI}_{j}=$ Corporate Social Responsibility Disclosure Index Perusahaan $\mathrm{j}\left(0 \leq \mathrm{CSRI}_{j} \leq 1\right)$

$\mathrm{X}_{\mathrm{ij}} \quad=$ Jumlah item yang diungkapkan perusahaan $\mathrm{j}$

$\mathrm{n}_{\mathrm{j}} \quad=$ Total item GRI-G4

\section{Kinerja Perusahaan}

Kinerja perusahaan merupakan gambaran keadaan ekonomi suatu perusahaan dalam mengelola sumber daya yang dimiliki selama periode waktu tertentu (Helfert, 1996). Indikator Tobin's Q digunakan dalam penelitian untuk mengukur kinerja perusahaan. Tobin's $Q$ mencerminkan nilai perusahaan kepada shareholder dan memiliki tingkat keterbandingan antar perusahaan yang lebih tepat, karena tidak menggunakan financial accounting information yang 


\section{PERFORMANCE}

Jurnal Personalia, Financial, Operasional,

Marketing dau Sistem Informasi

Performance. Volume 28 Nomor 1 Tahun 2021, 63-81

rentan manipulasi akuntansi, seperti depresiasi (Cho et al., 2019). Tobin's Q secara populer telah digunakan sebagai ukuran kinerja perusahaan karena mencerminkan eskpektasi pasar terhadap keuntungan masa depan (Mutakkin, 2012). Rasio Tobin's Q merujuk pada metode yang dikembangkan dalam penelitian Cho et al. (2019):

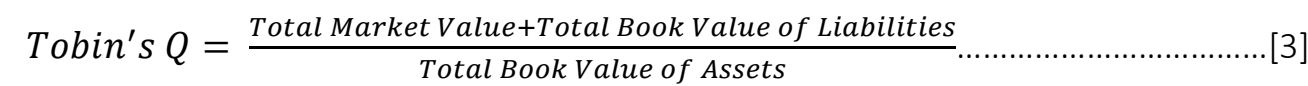

Total Market Value $=$ Total Outstanding Shares $x$ Current Share's Price..........[4]

\section{Teknik Analisis Data}

Statistik Deskriptif

Statistik deskriptif berkaitan dengan pengukuran nilai-nilai statistik seperti standar deviasi, mean, maksimun dan minimum yang akan memberikan gambaran mengenai perilaku dan distribusi data. Statistik deskriptif mempelajari bagaimana cara data yang digunakan dalam penelitian disusun dan disajikan (Suliyanto, 2011).

\section{Metode Analisis}

Pengujian data dalam penelitian menggunakan metode analisis Structural Equation Modeling (SEM)-Partial Least Square (PLS). SEM-PLS adalah analisis statistik multivariat yang dapat menganalisis seluruh variabel laten berserta indikator-indikator secara bersama-sama. Software SmartPLS 3.0 digunakan untuk melakukan uji PLS dengan langkah-langkah sebagai berikut:

\section{Model Pengukuran (Outer Model)}

Outer model adalah model pengukuran untuk menguji validitas konstruk dan reliabilitas instrumen (Jogiyanto, 2010). Model ini mendeskripsikan bagaimana hubungan antar variabel laten beserta indikator-indikatornya. Indikator dalam penelitian merupakan ukuran variabel laten yang tidak mempengaruhi variabel tersebut atau yang disebut sebagai model reflektif (Ghozali, 2008) Pengujian outer model ini terdiri atas:

\section{Uji Validitas}

Uji validitas memberikan ukuran keabsahan atau tidaknya suatu instrumen penelitian. Pengukuran validitas dengan menggunakan software SmartPLS dapat dilakukan dengan 2 cara yaitu convergent validity dan discriminant validity.

\section{Convergent Validity}

Convergent Validity diukur berdasarkan korelasi antara item score dengan construct score. Pengukuran ini dilakukan dengan cara melihat nilai loading factor pada tiap indikator. Apabila nilai loading factor menunjukkan angka dibawah 0,5 $(\alpha<0,5)$, maka indikator tersebut tidak memiliki korelasi yang cukup dengan konstruk (Ghozali, 2008).

\section{Discriminant validity}

Discriminant validity mengukur bagaimana korelasi konstruk dengan indikatornya. Apabila nilai korelasi konstruk lebih besar dibandingkan konstruk lainnya, maka konstruk laten tersebut memprediksi ukuran yang lebih baik, sehingga dapat disimpulkan memiliki nilai discriminant validity yang baik (Ghozali, 2008).

\section{Uji Reliabilitas}

Reliabilitas mencerminkan skala pengukuran yang digunakan dalam penelitian menunjukkan konsistensi dan stabilitas. Reliabilitas dievaluasi menggunakan nilai composite reliability dan Cronbach Alpha pada setiap konstruk. Jika nilai output composite reliability lebih besar dari 0,7 ( $\alpha$ $>0,7)$, maka variabel lolos uji reliabilitas (Ghozali, 2008). Nilai output Cronbach Alpha dapat 
Performance. Volume 28 Nomor 1 Tahun 2021, 63-81

diterima apabila lebih besar dari 0,6 $(\alpha>0,6)$, sehingga konstruk dinyatakan reliabel (Ghozali, 2008).

\section{Model Struktural (Inner Model)}

Inner model atau model struktural menunjukkan bagaimana hubungan hubungan antara konstruk atau variabel laten berdasarkan teori substantifnya. Inner model diukur menggunakan nilai $R$-square. Perubahan nilai $R$-square menunjukkan pengaruh substantif variabel laten independen terhadap variabel laten dependen. Nilai $R$-square yang tinggi mencerminkan semakin baik model dalam memprediksi hubungan kausalitas variabel independen terhadap variabel dependen (Ghozali, 2008).

Pengujian hipotesis dilakukan dengan mengevaluasi nilai $t$ statistik pada output path coefficient setelah dilakukan pengujian bootstrapping. Seperti halnya uji t, pengujian hipotesis ini membandingkan antara nilai $t_{\text {statistik }}$ dan $t_{\text {tabel }}$. Apabila nilai $t_{\text {statistik }}$ lebih besar dibandingkan $t_{\text {tabel }}$ $\left(t_{\text {statistik }}>t_{\text {tabel }}\right)$, maka dapat disimpulkan bahwa terdapat pengaruh signifikan antara kedua konstruk. Tetapi sebalinya, apabila nilai $t_{\text {statistik }}$ lebih kecil dibandingkan $t_{\text {tabel }}\left(t_{\text {statistik }}<t_{\text {tabel }}\right)$, maka tidak ada pengaruh signifikan antara kedua konstruk. Nilai $t_{\text {tabel }}$ yang digunakan dalam penelitian ini adalah 1,96 (hipotesis dua ekor atau two tailed), dengan tingkat signifikansi 5\%.

\section{Uji Efek Mediasi}

Variabel corporate social responsibility sebagaimana disebutkan dalam penelitian merupakan variabel mediasi, karena mempengaruhi hubungan tidak langsung pengaruh variabel family ownership terhadap variabel kinerja perusahaan. Baron dan Kenny (1986) mengungkapkan beberapa kondisi yang harus dipenuhi variabel mediasi sebagai berikut: (a) Variabel independen secara signifikan berpengaruh terhadap variabel mediasi; (b) Variabel mediasi berpengaruh signifikan terhadap variabel dependen; dan (c) Ketika kondisi a dan b dikendalikan, efek utama pengaruh variabel independen terhadap variabel dependen menjadi tidak signifikan, karena dimediasi oleh variabel intervening atau mediasi.

Output Total Effect digunakan sebagai parameter uji signifikansi efek mediasi. Dalam konteks ini, parameter uji signifikansi tidak dilihat dari output path coefficient, karena efek mediasi tidak hanya menguji pengaruh langsung variabel independen terhadap variabel dependen (direct effect), tetapi juga pengaruh tidak langsung antara variabel independen dan variabel dependen (indirect effect) melalui variabel intervening (Jogiyanto dan Abdillah, 2009).

Pengujian efek mediasi dilakukan dengan menggunakan metode VAF dengan langkahlangkah sebagai berikut: (1) Menguji pengaruh langsung (tanpa memasukkan variabel mediasi ke dalam model) harus signifikan; (2) Menguji pengaruh tidak langsung (dengan memasukkan variabel mediasi ke dalam model) harus signifikan; dan (3) Penghitungan nilai VAF (Sholihin, M., Ratmono, 2013).

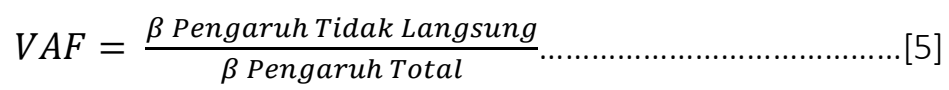

Jika nilai VAF lebih dari 80\% (> 80\%), maka efek mediasi disebut sebagai efek mediasi penuh (full mediation). Nilai VAF 20\%-80\% menjukkan bahwa variabel mediasi memiliki efek mediasi parsial (partial mediation). Selanjutnya, apabila nilai VAF di bawah 20\% (<20\%), maka dapat disimpulkan bahwa tidak terdapat efek mediasi (Sholihin dan Ratmono, 2013).

\section{HASIL DAN PEMBAHASAN}

\section{Analisis Deskriptif}

Analisis deskriptif menunjukkan rataan nilai minimum, maksimun, mean, dan standar deviasi dari data penelitian yang memberikan gambaran mengenai distribusi data tersebut. Data diperoleh melalui analisis konten (content analysis) dan pengukuran tertentu dari publikasi 
Jurnal Personalia, Financial, Operasional,

Marketing dau Sistem Informasi

Performance. Volume 28 Nomor 1 Tahun 2021, 63-81

annual report 65 perusahaan sektor infrastruktur, utilitas, transportasi dan industri properti, real estate serta konstruksi bangunan pada website www.idx.co.id selama periode tahun 2018.

Tabel 1. Statistik Deskriptif

\begin{tabular}{lccccc}
\multicolumn{1}{c}{ Variabel } & N & Minimum & Maksimum & Mean & $\begin{array}{c}\text { Standar } \\
\text { Deviasi }\end{array}$ \\
\hline Famow & 65 & 21 & 89 & 51,938 & 19,062 \\
CSR & 65 & 24 & 85 & 60,308 & 12,905 \\
Kinerja & 65 & 63 & 353 & 135,169 & 44,164 \\
\hline
\end{tabular}

Sumber: Data diolah, 2020

Data pada tabel 1 menunjukkan bahwa variabel family ownership (famow) mempunyai kisaran teoritis antara 21-89, dengan nilai rata-rata 51,938 dan standar deviasi sebesar 19,062. Sedangkan, untuk variabel corporate social responsibility (CSR) memiliki kisaran teoritis antara 2485 , dengan nilai rata-rata dan standar deviasi masing-masing sebesar 60,308 dan 12,905. Variabel Kinerja Perusahaan (Kinerja) mempunyai kisaran teoritis antara 63-353 dengan nilai rata-rata 135,169 dan standar deviasi sebesar 44,164.

\section{Uji Outer Model}

Outer model menggambarkan bagaimana konstruk atau variabel laten diukur dengan indikator-indikatornya. Model ini mengukur seberapa besar tingkat validitas dan reliabilitas dari data yang telah dikumpulkan. Model struktural sebagaimana dapat dilihat pada gambar 2 dibawah ini, diuji melalui:

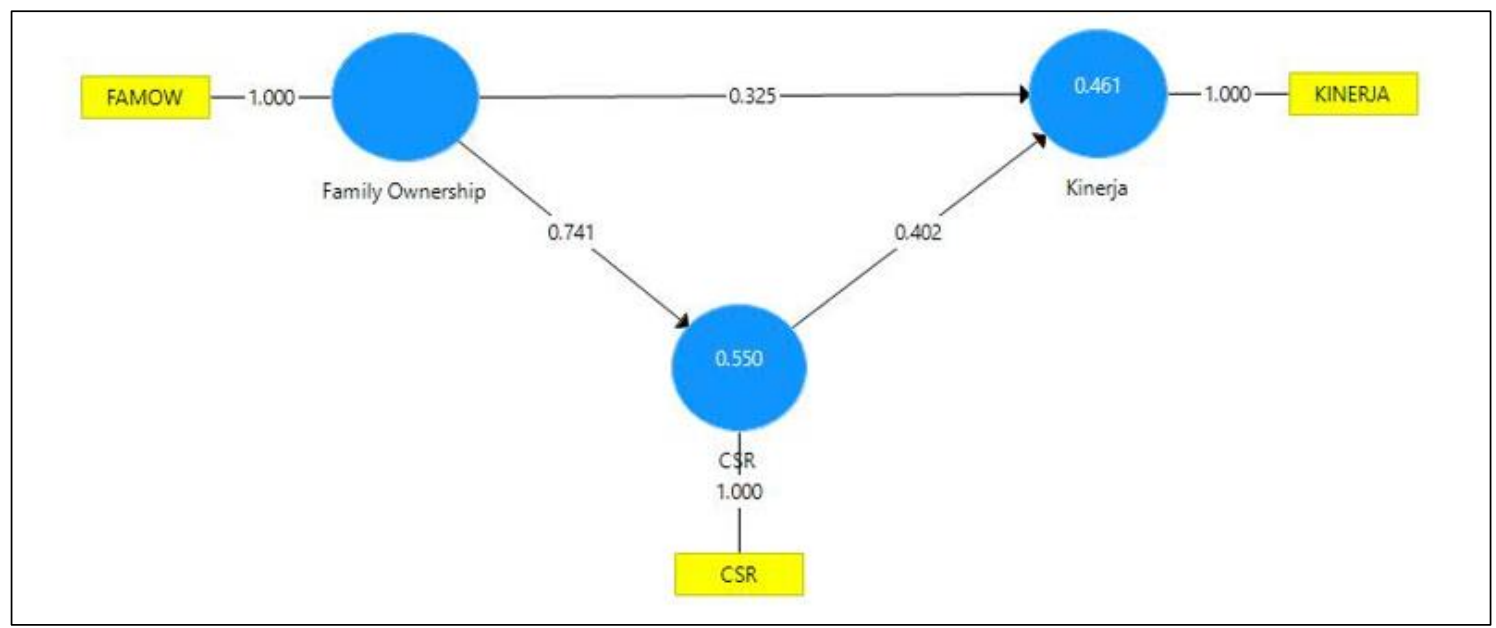

Gambar 2 Output Model Struktural.

\section{Convergent Validity}

Hasil output SmartPLS 3.0 pada gambar 2 menunjukkan bahwa semua indikator memiliki nilai loading factor di atas 0,50. Nilai loading factor dari setiap variabel famow, CSR dan kinerja adalah sebesar 1,00 (1,00>0,50). Dengan demikian, dapat disimpulkan bahwa semua indikator dari masing-masing konstruk dinyatakan valid.

\section{Dicriminant Validity}

Hasil pengujian discriminant validity pada tabel 2 menunjukkan bahwa nilai cross loading untuk setiap indikator dari masing-masing variabel lebih besar dibandingkan dengan nilai cross loading pada ukuran kostruk lainnya. Hal ini berarti bahwa setiap indikator sudah memiliki discriminant validity yang baik. 
Jurnal Personalia, Financial, Operasional,

Markeling dau Sistem Informasi

Performance. Volume 28 Nomor 1 Tahun 2021, 63-81

Tabel 2. Nilai Discriminant Validity

\begin{tabular}{cccc}
\hline & CSR & Famow & Kinerja \\
\hline CSR & 1,000 & 0,741 & 0,643 \\
\hline Famow & 0,741 & 1,000 & 0,623 \\
\hline Kinerja & 0,643 & 0,623 & 1,000 \\
\hline \multicolumn{3}{c}{ Sumber: Data diolah, 2020 }
\end{tabular}

Tabel 3. Composite Reability Cronbachs Alpha

\begin{tabular}{ccc}
\hline Composite Reliability & $\begin{array}{c}\text { Cronbachs } \\
\text { Alpha }\end{array}$ \\
\hline CSR & 1,00 & 1,00 \\
\hline Famow & 1,00 & 1,00 \\
\hline Kinerja & 1,00 & 1,00 \\
\hline
\end{tabular}

Sumber: Data diolah, 2020

Tabel composite reability dan cronbachs alpha menunjukkan bahwa semua variabel memenuhi kriteria reliabel. Nilai composite reability lebih dari 0,7 dan nilai cronbachs alpha yang di atas 0,6 pada masing-masing variabel famow, CSR dan kinerja.

\section{Uji Inner Model}

Inner model menunjukkan bagaimana hubungan hubungan antara konstruk atau variabel laten berdasarkan teori substantifnya. Inner model diukur menggunakan nilai $R$-square.

Tabel 4 Nilai $R$-square

\begin{tabular}{cc}
\hline & $R$ Square \\
\hline CSR & 0,550 \\
\hline Kinerja & 0,461 \\
\hline & Sumber: Data diolah, 2020
\end{tabular}

Hasil pengujian menunjukkan bahwa nilai $R$-square untuk masing-masing variabel kinerja dan CSR adalah sebesar 0,461 dan 0,550. Hasil ini menjelaskan bahwa variabel kinerja perusahaan dipengaruhi oleh variabel family ownership dan CSR sebesar 46,1\%. Sementara untuk variabel corporate social responsibility mendapat pengaruh sebesar 55,0\% dari variabel family ownership.

\section{Uji Hipotesis}

Dasar pengujian hipotesis adalah nilai statistik yang dihasilkan pada output path coefficients sebagaimana disajikan pada tabel 5 berikut ini:

Tabel 5. Path Coefficients

\begin{tabular}{lccccc} 
& $\begin{array}{c}\text { Original } \\
\text { Sample }(O)\end{array}$ & $\begin{array}{c}\text { Sample Mean } \\
(M)\end{array}$ & $\begin{array}{c}\text { Standard Deviation } \\
(\text { STDEV })\end{array}$ & $\begin{array}{c}\text { TStatistics } \\
(\text { /O/STERR /) }\end{array}$ & $\begin{array}{c}P \\
\text { Values }\end{array}$ \\
\hline CSR -> Kinerja & 0,402 & 0,411 & 0,105 & 3,809 & 0,000 \\
\hline Famow -> CSR & 0,741 & 0,743 & 0,060 & 12,305 & 0,000 \\
\hline Famow -> Kinerja & 0,325 & 0,326 & 0,122 & 2,664 & 0,008 \\
\hline
\end{tabular}


Performance. Volume 28 Nomor 1 Tahun 2021, 63-81

Pengujian Hipotesis 1 (Family ownership berpengaruh terhadap kinerja perusahaan)

Data pada tabel path coefficients menunjukkan bahwa variabel family ownership dan kinerja perusahaan memiliki hubungan positif dengan nilai koefisien jalur sebesar 0,325 . Nilai $t_{\text {statistik }}$ sebesar 2,664 yang lebih besar dari 1,96 (hipotesis two tailed) mengindikasikan bahwa varibel family ownership memiliki pengaruh signifikan terhadap kinerja perusahaan. Hasil ini didukung dengan nilai $p$ values 0,008 kurang dari 0,05 $(0,008<0,05)$. Sehingga, dapat disimpulkan bahwa hipotesis 1 diterima.

Hasil penelitian mendukung temuan penelitian terdahulu seperti Astrachan dan Shanker (2003), Muttakin (2012), Perdana dan Kusumastuti (2011), Brand et.al, (2018), Pindado et al. (2008), Yoshikawa dan Rasheed (2010) yang menemukan bahwa family ownership berpengaruh positif terhadap kinerja perusahaan. Perspektif keluarga yang memprioritaskan perusahaan sebagai aset keluarga telah mendorong perusahaan untuk berorientasi bisnis jangka panjang. Mereka memiliki komitmen dan sense of belonging yang tinggi untuk bagaimana caranya mempertahankan dan mengembangkan usaha keluarganya. Data penelitian mengungkapkan bahwa family business merupakan usaha yang telah dijalankan satu generasi ke generasi berikutnya dengan jangka waktu yang panjang. Masa kerja ini memberikan family business pengetahuan dan sumber daya untuk meningkatkan produktivitas, customer relationship, hubungan stakeholder serta inovasi yang mengarah pada kinerja perusahaan perusahaan yang lebih baik.

Family business memberikan alternatif struktur kepemilikan perusahaan untuk menghadapi tantangan revolusi industri 4.0. Jensen dan Meckling (1976) dalam teori agensi menjelaskan bahwa kehadiran pendiri dalam perusahaan dapat menyelaraskan kepentingan prinsipal dan agen. Konsentrasi kepemilikan keluarga akan membuat prinsipal memiliki insentif, informasi dan kekuatan untuk mengendalikan manajer. Manajer tidak lagi dianggap sebagai agen yang berusaha mencapai tujuan pribadi, tetapi sebagai pihak yang menganggap kesuksesaan perusahaan adalah tanggung jawab mereka. Dengan demikian, mitigasi agency problem dan aliansi kepemilikan keluarga dengan manajemen akan memungkinkan kebijakan perusahaan untuk berorientasi pada pencapaian tujuan perusahaan.

Pengujian Hipotesis 2 (Family ownership berpengaruh terhadap corporate social responsibility)

Hasil pengujian hipotesis 2 menunjukkan bahwa hubungan variabel family ownership dengan corporate social responsibility memiliki nilai koefisien jalur sebesar 0,741 dan $t_{\text {statistik }}$ sebesar 12,305 . Hasil ini mengindikasikan bahwa variabel family ownership berpengaruh positif dan signifikan terhadap variabel corporate social responsibility. Nilai $p$ values $0,000<0,05$ mendukung kesimpulan bahwa hipotesis 2 diterima.

Reputasi perusahaan tidak hanya mencerminkan kinerja perusahaan, tetapi juga nama baik keluarga. Keluarga sebagai pemilik perusahaan akan memberikan perhatian lebih besar terhadap aktivitas-aktivitas yang berpengaruh positif terhadap reputasi perusahaan. Reputasi perusahaan yang buruk akan menghancurkan nama baik keluarga dan kinerja perusahaan itu sendiri. Sehingga, family business akan berinvestasi lebih besar dalam kegiatan CSR untuk meningkatkan reputasi perusahaan yang akan berdampak positif terhadap nama baik keluarga. Hasil ini mendukung penelitian yang telah dilakukan Dyer dan Whetten (2006), Berrone et al. (2010), Liu et al. (2017) dan Palma et al. (2018) yang mengungkapkan bahwa family ownership memiliki pengaruh signifikan terhadap corporate social responsibility (CSR).

Hasil output $R$-square menunjukkan bahwa variabel family ownership dapat menjelaskan variabel corporate social responsibility sebesar 0,550 atau 55\%. Hal ini mengindikasikan bahwa kepemilikan keluarga dalam perusahaan dapat mempengaruhi kebijakan perusahaan untuk memenuhi harapan relatif dari para stakeholder. Orientasi jangka panjang family business akan mendorong perusahaan untuk mengidentifikasi kebutuhan stakeholder, merancang kebijakan, dan pratik organisasi yang tepat melalui kegiatan CSR. 


\section{PERFORMANCE}

Jurnal Personalia, Financial, Operasional,

Marketing dau Sistem Informasi

Performance. Volume 28 Nomor 1 Tahun 2021, 63-81

Pengujian Hipotesis 3 (Corporate social responsibility memediasi pengaruh family ownership terhadap kinerja perusahaan)

Berdasarkan tabel path coefficients dapat disimpulkan bahwa variabel corporate social responsibility berpengaruh positif dan signifikan terhadap kinerja perusahaan, dengan nilai koefisien jalur sebesar 0,402 dan $t_{\text {statistik }}$ sebesar 3,809. Namun untuk menguji efek mediasi pada hipotesis ini, output parameter yang dilihat bukan pada tabel path coefficients, melainkan tabel total indirect effect sebagaimana disajikan pada tabel berikut ini.

Tabel 6. Total Indirect Effect

\begin{tabular}{lccccc} 
& Original & Sample Mean & Standard Deviation & TStatistics & $P$ \\
Sample (O) & (M) & (STDEV) & (|O/STERR/) & Values \\
\hline CSR $>$ Kinerja & & & & &
\end{tabular}

\begin{tabular}{|c|c|c|c|c|c|}
\hline \multicolumn{6}{|l|}{ Famow $->$ CSR } \\
\hline Famow -> Kinerja & 0,298 & 0,306 & 0,083 & 3,572 & 0,000 \\
\hline
\end{tabular}

Tabel Total Indirect Effect menunjukkan bahwa nilai $t_{\text {statistik }}$ lebih besar dibandingkan 1,96 $(3,572>1,96)$. Hal ini mengindikasikan variabel corporate social responsibility sebagai variabel intervening yang memediasi pengaruh tidak langsung variabel family ownership terhadap kinerja perusahaan. Nilai $p$ values $0,000<0,05$ menguatkan kesimpulan bahwa hipotesis 3 untuk efek mediasi diterima.

Pengujian efek mediasi dengan metode VAF digunakan untuk menunjukkan seberapa besar pengaruh variabel intervening dalam memediasi hubungan tidak langsung antara variabel independen terhadap variabel dependen. Hasil pengujian menghasilkan nilai VAF sebagai berikut:

\section{Pengaruh langsung}

Tabel 7. Path Coefficients Pengaruh Langsung

\begin{tabular}{lccccc}
\hline & $\begin{array}{c}\text { Original } \\
\text { Sample (O) }\end{array}$ & $\begin{array}{c}\text { Sample Mean } \\
(\mathbf{M})\end{array}$ & $\begin{array}{c}\text { Standard Deviation } \\
\text { (STDEV) }\end{array}$ & $\begin{array}{c}\text { T Statistics } \\
\text { (|O/STERR/) }\end{array}$ & P Values \\
\hline Famow -> Kinerja & 0,358 & 0,326 & 0,140 & 2,564 & 0,011 \\
\hline
\end{tabular}

Data pada tabel 7 menunjukkan bahwa pengaruh langsung variabel family ownership terhadap kinerja perusahaan memiliki nilai koefisien jalur sebesar 0,358, Nilai $t_{\text {statistik }} 2,564>1,96$ dan $p$ values $0,011<0,05$. Hal ini mengindikasikan bahwa family ownership berpengaruh signifikan terhadap kinerja perusahaan.

\section{Pengaruh Tidak Langsung}

Data pada tabel 6 Total Indirect Effect di atas telah menunjukkan bahwa variabel corporate social responsibility memediasi pengaruh tidak langsung variabel family ownership terhadap kinerja perusahaan dengan nilai koefisien jalur sebesar 0,298 , $\mathrm{t}_{\mathrm{statistik}}$ 3,572 >1,96, dan $p$ values $0,000<0,05$.

\section{Penghitungan Nilai VAF}

$$
\begin{array}{r}
V A F=\frac{\beta \text { Pengaruh Tidak Langsung }}{\beta \text { Pengaruh Total }} \ldots \ldots \ldots \ldots \ldots \ldots \ldots \ldots \\
\quad=\frac{0,298}{0,656}=0,454(45.4 \%)
\end{array}
$$

Penghitungan di atas menunjukkan nilai VAF 0,454 atau 45,4\%. Hal ini berarti bahwa variabel corporate social responsibility memiliki efek mediasi partial (partial mediation) dalam hubungan tidak langsung antara family ownership dan kinerja perusahaan. 
Performance. Volume 28 Nomor 1 Tahun 2021, 63-81

Teori stakeholder memberikan suatu pandangan bahwa kelangsungan hidup jangka panjang perusahaan berkaitan dengan pemenuhan kepentingan ekonomi dan non-ekonomi para stakeholder melalui kegiatan CSR. Data pengungkapan CSR yang diukur berdasarkan standar Global Reporting Initiative (GRI)-G4 menunjukkan nilai mean 60,308. Perusahaan sektor infrastruktur, utilitas, transportasi dan industri properti, real estate serta konstruksi bangunan yang terdaftar di Bursa Efek Indonesia (BEI) telah memahami pentingnya CSR sebagai strategi perusahaan untuk meningkatkan reputasi perusahaan di hadapan para stakeholder. CSR tidak hanya memberikan manfaat pada peningkatan loyalitas investor, tetapi juga loyalitas pelanggan, penerimaan masyarakat, dan peningkatan aset tak berwujud yang akan berdampak positif terhadap kinerja keuangan jangka panjang perusahaan.

Orientasi jangka panjang yang dimiliki family business akan mendorong perusahaan untuk berinvestasi jangka panjang dengan para pemangku kepentingan untuk menjamin kelangsungan usaha perusahaan berlanjut dari satu generasi ke generasi berikutnya. Perusahaan berinvestasi dalam kegiatan CSR untuk meningkatkan reputasi mereka dihadapan para stakeholder. Perspektif reputasi yang menganggap bahwa reputasi perusahaan tidak hanya mencerminkan kinerja perusahaan tetapi juga nama baik keluarga, akan mendorong perusahaan untuk melakukan kegiatan yang tidak bertentangan dengan stakeholder. Peningkatan aktivitas CSR pada perusahaan dapat memenuhi harapan relatif para pemangku kepentingan (stakeholder), yang akan direspon dengan peningkatan nilai perusahaan. Argumentasi ini didukung dengan hasil pengujian $R$-square yang menunjukkan bahwa variabel family ownership dan CSR dapat mempengaruhi 0,461 atau 46,1\% variabel kinerja perusahaan.

\section{KESIMPULAN}

Family ownership berpengaruh positif dan signifikan terhadap kinerja perusahaan

Family ownership sebagai representasi unsur keluarga dalam perusahaan memiliki pengaruh positif dan signifikan terhadap kinerja perusahaan. Mitigasi agency problem dan orientasi bisnis jangka panjang family business mendorong perusahaan untuk mencapai kinerja keuangan yang lebih baik, sehingga perusahaan dapat berlanjut dari satu generasi ke generasi berikutnya.

Family ownership berpengaruh positif dan signifikan terhadap corporate social responsibility Perspektif keluarga terhadap reputasi dan nama baik keluarga akan mendorong perusahaan untuk meningkatkan pengungkapan CSR, sehingga perusahaan dipandang sebagai entitas korporasi yang baik.

\section{Corporate social responsibility memediasi pengaruh family ownership terhadap kinerja perusahaan}

Keluarga sebagai pemilik perusahaan akan mendorong pengungkapan CSR untuk menunjukkan komitmen perusahaan terhadap tanggung jawab sosial dan lingkungan, sehingga akan direspon stakeholder sebagai sinyal positif terhadap prospek dan keberlanjutan jangka panjang perusahaan.

\section{Implikasi}

Family business memberikan alternatif struktur kepemilikan bagi perusahaan untuk menghadapi tantangan revolusi industri 4.0. Kehadiran keluarga dalam perusahaan dapat menyeleraskan kepentingan dan asimetri informasi antara prinsipal dan agen, sehingga agency problem dapat diminimalkan. Kebijakan perusahaan akan berorientasi pada pencapaian tujuan perusahaan untuk dapat memenangkan persaingan global.

Hasil penelitian memberikan rekomendasi bagi family business dalam menganalisis komponenkomponen yang dapat mempengaruhi kinerja perusahaan. Variabel corporate social responsibility telah dibuktikan secara ilmiah memediasi pengaruh tidak langsung variabel family 


\section{PERFORMANCE}

Jurnal Personalia, Financial, Operasional,

Marketing dau Sistem Informasi

Performance. Volume 28 Nomor 1 Tahun 2021, 63-81

ownership terhadap kinerja perusahaan. Perspektif keluarga mengenai reputasi perusahaan dan orientasi bisnis jangka panjang akan mendorong perusahaan untuk berinvestasi dalam kegiatan CSR untuk menjamin kelangsungan usaha perusahaan.

\section{Keterbatasan}

Teknik purposive sampling membatasi interpretasi hasil penelitian yang tidak dapat digeneralisasi pada semua perusahaan. Interpretasi hasil penelitian terbatas pada perusahaan yang bergerak di sektor industri infrastruktur, utilitas, dan transportasi serta industri properti, real estate, dan konstruksi bangunan yang terdaftar di Bursa Efek Indonesia periode 2018. Hal ini diharapkan menjadi pertimbangan penelitian selanjutnya untuk mengembangkan sampling frame yang digunakan dalam membahas fenomena atau permasalahan yang berkembang di masyarakat.

\section{DAFTAR PUSTAKA}

Association of Certified Fraud Examiners (ACFE). (2016). Survai Fraud Indonesia.

Astrachan, Joseph, H., Shanker, M, C. (2003). Family Businesses' Contribution to the U.S. Economy: A Closer Look. Family Business Review, Vol XVI No.

Atmaja Lukas, S. (2008). Corporate Governance in Family Firms. Jurnal Manajemen Dan Bisnis, Vol.1, No., 103-115.

Baron, M, Reuben., Kenny, A. (1986). The Moderator-Mediator Variable Distinction in Social Psychological Research: Conceptual, Strategic, and Statistical Considerations. Journal of Personality and Social Psychology, Vol. 51, N, 1173-1182.

Berrone, P., Cruz, C., Gómez-Mejía, L., Larraza-Kintana. (2010). Socioemotional Wealth And Corporate Responses To Institutional Pressures: Do Family-Controlled Firms Pollute Less? Administrative Science Quarterly, 82-113.

Camisón-Zornoza, C., Forés-Julián, B., Puig-Denia, A., \& Camisón-Haba, S. (2020). Effects of ownership structure and corporate and family governance on dynamic capabilities in family firms. International Entrepreneurship and Management Journal, 16(4), 1393-1426. https://doi.org/10.1007/s11365-020-00675-w

Charbel, Salloum., Elie, Bouri., Georges, Samara. (2013). Impact of Family Involvement in Ownership Management and Direction on Financial Perfomance of the Lebanese Firms. International Strategic Management Review, 30-41.

Clarkson, M, B, E. (1995). A Stakeholder Framework for Analysing and Evaluating Corporate Social Performance. Academy of Management Review, Vol. 20 No, Hal 92-11.

Davis, J.H., Allen, M.R., Hayes, H. . (2010). Is Blood Thicker Than Water? A Study of Stewardship Perceptions in Family Business. Entrepreneurship Theory and Practice, 34(6, 1093-1116.

Deephouse, David L., Carter, S. M. (2013). An Examination of Differences between Organizational Legitimacy and Organizational Reputation. Journal of Management Studies, 42:2.

Dyer, W., Whetten, D. (2006). Family Firms and Social Responsibility: Preliminary Evidence from the SP 500. Entrepreneurship Theory and Practice, 30, 785-802.

Foroughi, Meysam., Fooladi, M. (2011). Corporate Ownership Structure and Firm Perfomance: 
Jurnal Personalia, Financial, Operasional,

Marketing dau Sistem Informasi

Performance. Volume 28 Nomor 1 Tahun 2021, 63-81

Evidence from Listed Firms in Iran. International Conference on Humanities, Society and Culture, 20.

Ghoul, S.E., Guedhami O., Kwok C.C.Y., W. H. (2016). Family Control and Corporate Social Responsibility. The 2015 International Corporate Governance Society Conference.

Ghozali, I. (2008). Structural Equation Modeling, Metode Alternatif dengan Partial Least Square. Badan Penerbit Universitas Diponegoro.

Hidayanti, A. N. (2013). Pengaruh Antara Kepemilikan dan Corporate Governance terhadap Tindakan Pajak Agresif. UNDIP.

International, K. (2018). Survey of European Family Business Barometer.

Jensen, Michael. C., Meckling, W. H. (1976). Theory of the Firm: Manajerial Behavior, Agency Cost and Ownership Structure. Journal of Financial Economics, 3, 305-360.

Jogiyanto, H. (2010). Metodologi Penelitian Bisnis: Salah Kaprah dan Pengalaman-pengalaman. Badan Penerbit Fakultas Ekonomika dan Bisnis UGM.

Lam, Newman, M. (2000). Government Intervention in the Economy: A Comparative Analysis of Singapore and Hong Kong. Public Administration and Development, 20, 397-421.

Liu, Mingzhi., Shi Y., Wilson C., W. Z. (2017). Does Family Involvement Explain Why Corporate Social Responsibility Affects Earning Management? Journal of Business Research, 8-16.

Luayyi, S. (2012). Teori Keagenan dan Manajemen Laba dari Sudut Pandang Etika Manajer. Universitas Brawijaya.

LV, P., Li, Y., \& Mitra, D. (2020). CSR and performance of family businesses: A systematic review. Australasian Accounting, Business and Finance Journal, 14(3), 75-85.

Manogna, R. L., \& Kumar, M. A. (2020). Exploring the role of family ownership in internationalization: empirical investigation of Indian firms. In Review of International Business and Strategy: Vol. ahead-of-print (Issue ahead-of-print). https://doi.org/10.1108/RIBS-05-2020-0058

Maseda, Amaia., Itturalde T., Aparicio G., Boulkeroua L., C. S. (2018). Family Board Ownership, Generational Involvement and Perfomance in Family SMEs. European Journal of Management and Business Economics, 28(3).

McVea, John F., Freeman, E. R. (2005). A Names-And-Faces Approach To Stakeholder Management How Focusing on Stakeholders As Individuals Can Bring Ethics and Entrepreneurial Strategy Together. Journal of Management Inquiry, 14(1), 57-69.

Miller, Danny., Bretton-Miller, I. L. (2006). Family Governance and Firm Perfomance: Agency, Stewardship and Capabilities. Family Business Review, XIX(1).

Mishra, Supriti., Suar, D. (2010). Does Corporate Social Responsibility Influence Firm Perfomance of Indian Companies? Journal of Business Ethics, 571-601.

Muttakin, M. B. (2012). Family Firms, Board Structure, Political Connections and Perfomance: Evidence from Bangladesh. Deakin University. 
Jurnal Personalia, Financial, Operasional,

Marketing dau Sistem Informasi

Performance. Volume 28 Nomor 1 Tahun 2021, 63-81

Palma, Marta., Lourenco I.C., Branco, M. C. (2018). Sustainability Reporting In Family Versus NonFamily Firms: The Role of The Richest European Families.

Palmer, H. J. (2012). Corporate Social Responsibility and Financial Perfomance: Does it Pay Be Good?. CMC Senior Theses, 529.

Perdana, Ida, BP., Kusumastuti, R. (2011). Analysis of The Impact of Family Ownership on a Company's Costs of Debt. International Journal of Administrative Science Organization, 18(2).

Pindado, Julio., Requejo, Ignacio., Toree, C. de la. (2008). Does Family Ownership Impact Positively on Firm Value? Emipirical Evidence from Western Europe.

Purnamasari, L. (2018). ). Pengaruh Family Ownership Dan Proporsi Anggota Keluarga Pada Dewan Direksi Terhadap Kinerja Perusahaan (Studi Pada Perusahaan Barang Konsumsi Yang Terdaftar Di Bursa Efek Indonesia Tahun 2016. Universitas Lampung.

PwC (Pricewaterhouse Cooper). (2012). Family Firm: A Resilient Model for the 21st Century. Family Business Surve.

Roberts, W, R. (1992). Determinants of Corporate Social Responsibility Disclosure: An Application of Stakeholder Theory. Accounting Organizations and Society, 17(6), 595-612.

Shoimah, Irma L., Aryani, A. Y. (2019). Slack Resources, Family Ownership dan Pengungkapan Corporate Social Responsibility. Jurnal Reviu Akuntansi Dan Keuangan, 9(2).

Sholihin, M., Ratmono, D. (2013). Analisis SEM-PLS dengan WarpPLS 3.0. Penerbit ANDI.

Soerjonodibroto, T. (2010). Pratice of Directorship in Family Firms. Indonesian Institute for Corporate Directorship (IICD).

Suliyanto. (2011). Ekonometrika Terapan: Teori Aplikasi dengan SPSS. CV. Andi Offset.

Syamsi, Syam, S. (2015). Nawa Cita Jokowi-JK Dalam Paradigma Pembangunan Ekonomi. Surya Octagon Interdisciplinary Journal of Technology, 72-100.

Tanzil, Stephanie, N., J. (2017). Pengaruh Struktur Kepemilikan Keluarga Terhadap Kinerja Perusahaan Pada Sektor Perdagangan, Jasa dan Investasi. Business Accounting Review, 5(2).

Tjipto, Elsa, P., J. (2016). Pengaruh Corporate Social Responsibility Terhadap Nilai Perusahaan pada Sektor Properti dan Real Estate. Business Accounting Review, 4(1).

Villalonga, B., Amit, R. (2006). How Do Family Ownership, Control and Management Affect Firm Value? Journal of Financial Economic, 80(2), 385-417.

Wiranata, Yulius, A., Nugrahanti, Y. W. (2013). Pengaruh Struktur Kepemilikan Terhadap Profitabilitas Perusahaan Manufaktur di Indonesia. Jurnal Akuntansi Dan Keuangan, 15(1).

Yoshikawa, Toru., Rasheed, A. A. (2010). Family Control and Ownership Monitoring in FamilyControlled Firm in Japan. Journal of Management Studies, 47(2).

Yovita, Finda., J. (2017). Struktur Kepemilikan Keluarga dan Kinerja Perusahaan pada Sektor Aneka Industri. Business Accounting Review, 5(2). 


\section{PERFORMANCE}

Jumal Personalia, Financial, Operasional,

Performance. Volume 28 Nomor 1 Tahun 2021, 63-81

Yusuf, M. (2019). Strategi Manajemen Perubahan Pola Pikir SDM Guna Menghadapi Persaingan Era Industri 4.0 Pada Industri Manufaktur. In Seminar Nasional the 6th Call for Syariah Paper. UMS. 